\title{
Soil Classification and Seismic Site Response Analysis for Some Areas in Hanoi City
}

\author{
Giang Kien Trung ${ }^{1, *}$, Nguyen Duc Vinh ${ }^{1}$, Dang Thi Men ${ }^{2}$ \\ ${ }^{I}$ Faculty of Physics, VNU University of Science, 334 Nguyen Trai, Hanoi, Vietnam \\ ${ }^{2}$ K58 International Standard Program, Faculty of Physics, VNU University of Science, \\ 334 Nguyen Trai, Hanoi, Vietnam
}

Received 07 October 2017

Revised 24 March 2018; Accepted 26 March 2018

\begin{abstract}
Along with the development of urban and modern life, Hanoi Capital has been constructing more and more sky buildings, big bridges and huge underground constructions. According to historical studies, Hanoi is a region located on the weak soil ground which has a rather thick sedimentary layer, complicated geology structure and shallow ground water aged in the Holocene and Pleistocene. Hanoi city is cut through by a Red River fault which has been considered to be a strong active fault zone. As a consequence, it is able to cause earthquakes with magnitude $M=6.1$ corresponding to the $7^{\text {th }}$ ground vibration level in intensity. In order to predict the casualty of this severe earthquake being able to happen, it is surely essential to assess both seismic site response and geological conditions in Hanoi. In the paper, we will analyze the soil ground data and borehole data obtained in this region to find the specific geological factors which are put into the DeepSoil Program to evaluate local site effects.
\end{abstract}

Keywords: Modeling, local conditions, seismic site response analysis, site effect, soil classification.

\section{Introduction}

A lot of research about the effects of local soil conditions on earthquake has been carried out for a long time $[1,2]$. From the actual data collected through the major earthquakes that have occurred in the world combining with geotechnical surveys and with detailed exploration drilling, the general

\footnotetext{
${ }^{*}$ Corresponding author. Tel.: 84-983271180.

Email: trunggk@hus.edu.vn

https://doi.org/10.25073/2588-1094/vnuees.4185
}

theoretical basis to assess the effect of location conditions on earthquakes and their evaluation methods have been established. However, there have still been a lot of debates about these problems due to the diversity and complexity of the local geological conditions [1].

This research has also been paid attention in Vietnam so far, but the results are quite modest. It would also be mentioned that evaluating the effects of ground conditions on earthquake in Vietnam has some objective difficulties. The 
reason is that the levels of earthquake activities in the territory are moderate, the network of seismic observation stations distributed in Vietnam is sparse, and research funding is limitted. All these reasons are the tremendous difficulties to carry out the studies like these.

\section{Geology and faulting in the Northern Vietnam}

Although the seismicity in the Northern Vietnam is morderate, the infrustructure of Hanoi capital city is rapidly expanding along with the development of economics. The geologists show that Hanoi, the capital of Vietnam, is located on two main faults which are the Red River Fault (RRF) and Chay River Fault (CRF). These faults belong to the Red River Shear Zone (RRSZ) that comes from the Tibet and runs more than 1000 $\mathrm{km}$ to the Gulf of Tonkin. In the region of Vietnam, this shear zone forms two faults which are CRF in the northeast and RRF in the southwest. The RRF is also considered as the border of the South China Plate and the Indochina Plate. Recently, the geodynamic research in Kainozoi and Hanoi basin in Vietnam shows that the RRF is an active fault. At this time, the slip rate is from 1.1 to $1.8 \mathrm{~mm} /$ year $[3,4,5]$. In addition, the Northern Vietnam (Hanoi) also has many other active faults such as Chay river Fault, Song Lo Fault, Song Da Fault, Song Ma Fault as seen in the Figure 1.

According to Nguyen Quoc Cuong, Nguyen Trong Yem (2012), the most parts of alluvial sediments in Hanoi basin and Red river area were formed in the late Pleistocene and Holocene [7]. Surface geology was mainly sandy and clay sediments in Holocene or Pleistocene. The Holocene deposits are located at the depth of 10 $45 \mathrm{~m}$. The bottom of Pleistocene deposits was digging into the Neogene deposits is at the depth of $45 \mathrm{~m}$ in the north to $110 \mathrm{~m}$ in the south [8].

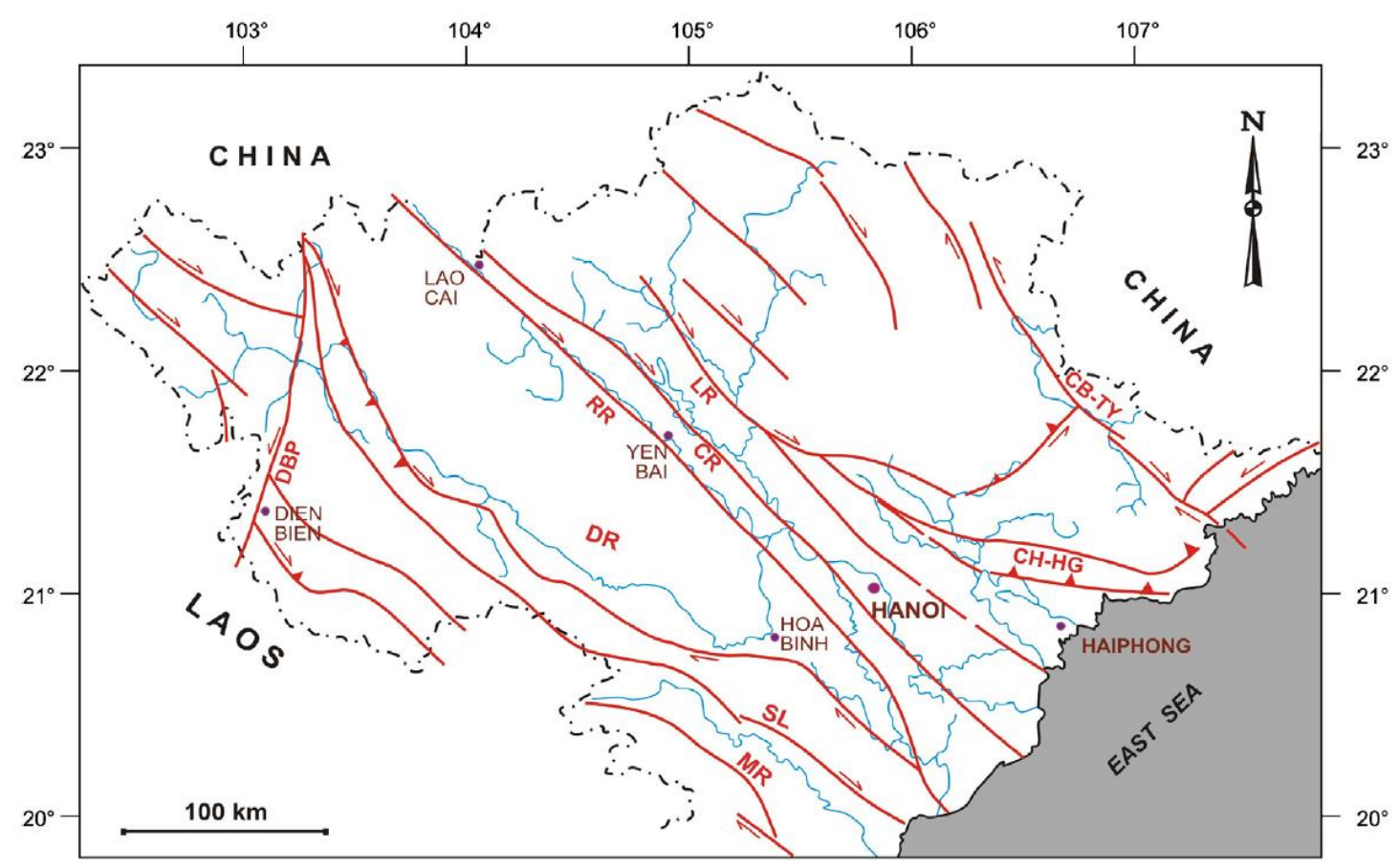

Figure 1. The map of the northern Vietnam with some major faults (RR: Red River, DR: Da River, CR: Cai River, LR: Lo River, MR: Ma River, DBP: Dien Bien Phu, CB-TY: Cao Bang- Tien Yen, CH-HG: Chi Linh - Hong Gai) [6]. 


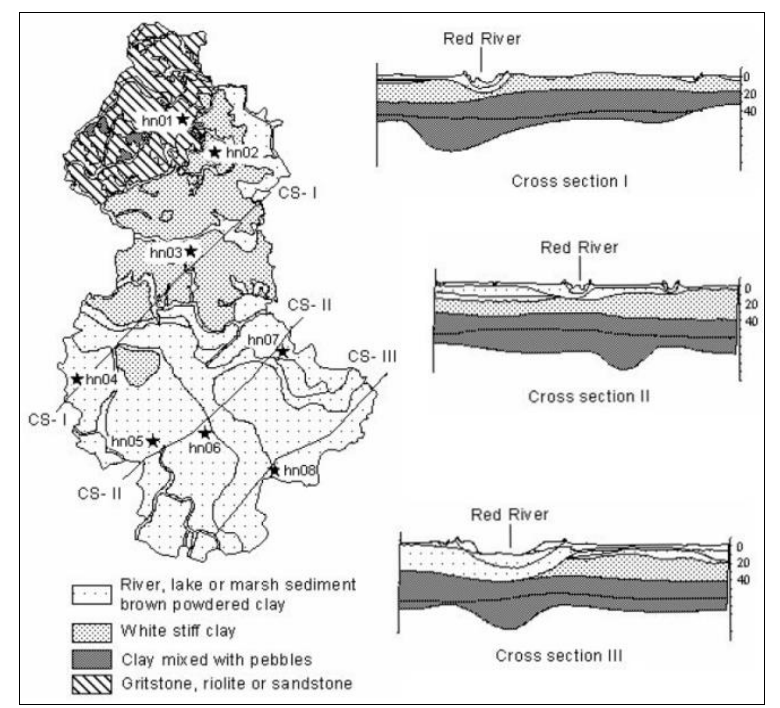

Figure 2. Geological map of Hanoi with the sections across the Red River Fault [9, 10].

\section{Site Class Definitions}

Based on the soil properties, the site is classified into six Site Classes as A, B, C, D, E and $\mathrm{F}$ in accordance with Table 1. When the soil properties are not known in sufficient detail to determine the site class, Site Class D will be used unless the building official or geo-technical data determines that Site Class E or F soil is likely to be present at that site.

Following Bui Thi Nhung and Nguyen Hong Phuong (2015), Hanoi region has all types of site classification, but mainly D, E and F types [13]. The distribution of site class $\mathrm{D}$ is dominated in the North-West of Hanoi, such as Tay Ho district, the Northen Thanh Xuan district, a part of Tu Liem district and small parts of Ha Dong, Long Bien district. The site class $\mathrm{E}$ appears nearly all areas of Gia Lam, Long Bien, Ha Dong, Hai Ba Trung, Hoan Kiem, Dong Da districts. The site class F was found in several regions as in Thanh Tri, Hoang Mai, Thanh Xuan districts and the Western Tu Liem district. In general, it is able to indicate that Hanoi ground is gradually weakening from the North-West to the South-East.

Table 1. Site Class Definitions as per International Building Code [11]

\begin{tabular}{|c|c|c|c|c|}
\hline \multirow{2}{*}{$\begin{array}{l}\text { Site } \\
\text { classification }\end{array}$} & \multirow[b]{2}{*}{ Description } & \multicolumn{3}{|c|}{ Average properties in top $30 \mathrm{~m}$} \\
\hline & & $\begin{array}{l}\text { Shear wave } \\
\text { velocity }(\mathrm{m} / \mathrm{s})\end{array}$ & $\begin{array}{l}\text { SPT N } \\
\text { (blows/300 mm) }\end{array}$ & $\begin{array}{l}\text { Undrained shear strength } \\
\mathrm{su}(\mathrm{kPa})\end{array}$ \\
\hline A & Hard rock & $>1500$ & NA & NA \\
\hline B & Rock & $750-1500$ & NA & NA \\
\hline $\mathrm{C}$ & $\begin{array}{l}\text { Very dense soil } \\
\text { and soft rock }\end{array}$ & $360-750$ & $>50$ & $>100$ \\
\hline $\mathrm{D}$ & Stiff soil & $180-360$ & $15-50$ & $50-100$ \\
\hline & & $<180$ & $<15$ & $<50$ \\
\hline $\mathrm{E}$ & Soft soil & \multicolumn{3}{|c|}{$\begin{array}{l}\text { Plus any profile with more than } 3 \mathrm{~m} \text { of soil having the following } \\
\text { characteristics: } \\
\text { Plasticity index, PI }>20 \% \\
\text { Moisture content, w } \geq 40 \% \\
\text { Undrained shear strength, } \mathrm{Su}<25 \mathrm{kPa}\end{array}$} \\
\hline $\mathrm{F}$ & \multicolumn{4}{|c|}{$\begin{array}{l}\text { Any profile containing soils with one or more of the follo } \\
\text { 1. Soil vulnerable to potential collapse under seismic loa } \\
\text { quick and highly sensitive clay, collapsible weakly ceme } \\
\text { 2. Peats and/or highly organic clays }(\mathrm{H}>8 \mathrm{~m} \text { of peat and } \\
\text { 3. Very high plasticity clays }(\mathrm{H}>8 \mathrm{~m} \text { with } \mathrm{PI}>75 \%) \\
\text { 4. Very thick soft/medium stiff clays }(\mathrm{H}>36 \mathrm{~m})\end{array}$} \\
\hline
\end{tabular}




\section{Some analysis results obtained from DeepSoil Program application}

Up to now, there has been a lot of programs to help us to analyze the response of ground motion, for example Shake 91, DeepSoil, Shake 2000, Strata or ShakeVT [14-16]. However, we have chosen DeepSoil to analyse. It is the software developped by the Department of Civil and Environmental Engineering in University of Illinois at Urbana-Champaign since 1998.
DeepSoil was based on the well-known code, the Shake and then they have upgraded this software with many new features: Graphical user interface; Animation for displacement; Analysis in both Frequency domain and Time domain. On the otherhand, the free software DeepSoil can run on the latest windows as windows 10 and contains a catalog of input motions and shear modulus. They are completely suitable with the present condition in Vietnam as we do not have lot of acceleration seismograms for modeling the site effect.

Table 2, 3. Results of shear wave velocity analysis (Vs) in the areas of North Linh Dam and Chua Boc, Hanoi city.

\begin{tabular}{|c|c|c|c|c|}
\hline 2 & BH K8 & , North Linh & Dam & \\
\hline Layer & Depth & Soil & SPT & Vs \\
\hline No. & (m) & Type & $(\mathrm{N})$ & $(\mathrm{m} / \mathrm{s})$ \\
\hline 1 & 2 & \multirow{6}{*}{$\begin{array}{l}\text { Loose fine } \\
\text { sand with } \\
\text { silt }\end{array}$} & & \\
\hline 2 & 3.5 & & 9 & 168 \\
\hline 3 & 8.5 & & 5 & 133 \\
\hline 4 & 21 & & 7.5 & 157 \\
\hline 5 & 23 & & 3 & 108 \\
\hline 6 & 24 & & 6 & 143 \\
\hline 7 & 36 & Medium & 12 & 189 \\
\hline 8 & 41 & dense silt & 8 & 161 \\
\hline 9 & 42.5 & $\begin{array}{l}\text { Stiff clay } \\
\text { silt }\end{array}$ & 18 & 222 \\
\hline 10 & 43.8 & $\begin{array}{l}\text { Very stiff } \\
\text { clay silt }\end{array}$ & $>50$ & \\
\hline
\end{tabular}

\begin{tabular}{|c|c|c|c|c|}
\hline 3 & $\mathrm{BH} 1, \mathrm{C}$ & Chua Boc & & \\
\hline Layer & Depth & Soil & SPT & Vs \\
\hline No. & (m) & Type & $(\mathrm{N})$ & $(\mathrm{m} / \mathrm{s})$ \\
\hline 1 & 2.5 & & & \\
\hline 2 & 3.5 & Loose fine & 7 & 152 \\
\hline 3 & 7 & sand with & 5 & 133 \\
\hline 4 & 16 & silt & 9 & 168 \\
\hline 5 & 20 & & 13 & 195 \\
\hline 6 & 25 & & 18 & 222 \\
\hline 7 & 32 & Medium & 5 & 133 \\
\hline 8 & 34 & dense silt & 11 & 183 \\
\hline 9 & 45 & and sand & 16 & 212 \\
\hline 10 & 52 & $\begin{array}{l}\text { Stiff clay } \\
\text { silt }\end{array}$ & 43 & 315 \\
\hline 11 & 53 & $\begin{array}{l}\text { Very stiff } \\
\text { clay silt }\end{array}$ & $>50$ & \\
\hline
\end{tabular}

Table 4, 5. Results of shear wave velocity analysis (Vs) in the areas of My Dinh II and Dai Kim, Hanoi city.

\begin{tabular}{lllll}
\hline 4 & \multicolumn{5}{l}{ BH1, My Dinh II } \\
\hline $\begin{array}{l}\text { Layer } \\
\text { No. }\end{array}$ & $\begin{array}{l}\text { Depth } \\
(\mathrm{m})\end{array}$ & $\begin{array}{l}\text { Soil } \\
\text { Type }\end{array}$ & $\begin{array}{l}\text { SPT } \\
(\mathrm{N})\end{array}$ & $\begin{array}{l}\text { Vs } \\
(\mathrm{m} / \mathrm{s})\end{array}$ \\
2 & 2 & & & \\
3 & 6.5 & Loose fine & 9 & 168 \\
4 & 13 & sand with & 12.5 & 192 \\
5 & 19 & silt & 2 & 92 \\
6 & 24 & & 5 & 133 \\
7 & 38.5 & $\begin{array}{l}\text { Medium } \\
\text { dense silt }\end{array}$ & 27 & 262 \\
8 & 41 & $\begin{array}{l}\text { Stiff clay } \\
\text { silt }\end{array}$ & 53 & 343 \\
9 & 45 & $\begin{array}{l}\text { Very stiff } \\
\text { clay silt }\end{array}$ & $>55$ \\
\hline
\end{tabular}

\begin{tabular}{|c|c|c|c|c|}
\hline 5 & BH K1 & , Dai Kim & & \\
\hline Layer & Depth & Soil & SPT & Vs \\
\hline No. & (m) & Type & $(\mathrm{N})$ & $(\mathrm{m} / \mathrm{s})$ \\
\hline 1 & 2 & Silt & & \\
\hline 2 & 4 & & 3 & 108 \\
\hline 3 & 25 & Loose fine & 9 & 168 \\
\hline 4 & 29 & $\begin{array}{l}\text { sand with } \\
\text { silt }\end{array}$ & 3 & 108 \\
\hline 5 & 36 & & 5 & 133 \\
\hline 6 & 37 & $\begin{array}{l}\text { Medium } \\
\text { dense silt }\end{array}$ & 13 & 195 \\
\hline 7 & 44 & Stiff & 25 & 254 \\
\hline 8 & 48 & clayey silt & 26 & 258 \\
\hline 9 & 50.5 & $\begin{array}{l}\text { Very stiff } \\
\text { clayey silt }\end{array}$ & $>100$ & \\
\hline
\end{tabular}


Depending on the estimation about the geological conditions of Hanoi capital city, we choose some boreholes data to analyse. The soil site models were chosen as $\mathrm{E}$ and $\mathrm{F}$ in the areas of Dong Da and Thanh Tri districts. Details about the soil models and shear wave velocity analysis results are described in the Tables 2, 3, 4 and 5.

Also, in this table, the 'Number of layers' and the 'Depth' are different due to the Depth of borehole in the field. Shear wave velocity denoted as $\mathrm{V}_{\mathrm{s}}$ is an important parameter to represent the stiffness of soil evaluated from SPT Number ' $N$ ' value. There are a lot of research in the world to estimate the shear wave velocity from the Standard Penetration Test value $(\mathrm{N})$ and in this paper, we use the predicted correlations of Aminaton Marto (2013) [16, 17].

The database of Deepsoil program offers a variety of acceleration but we have chosen the
Nahnni earthquake that happened on 23 December 1985 in Canada for our study. It is due to the earthquake magnitude $6.8(\mathrm{Mw})$ of Nahnni which is similar to the maximum $\mathrm{Mw}$ of earthquake possibly occuring in the Northern Vietnam $[18,19]$.

We have also chosen four boreholes in study area of around 45 meters in depth, which are two in Hoang Mai district, one in Dong Da district and one in Southern $\mathrm{Tu}$ Liem district. The geotechnical information from the borehole log analysis were calculated and estimated in detail as seen in the Tables 2, 3, 4 and 5. The 1D ground response modeling analysis was performed by using Deepsoil Program. The equivalent linear site response mode has been applied for analysis process. The results of spectral acceleration and Fourier amplitude analysis are shown in the Figures 3, 4, 5 and 6.
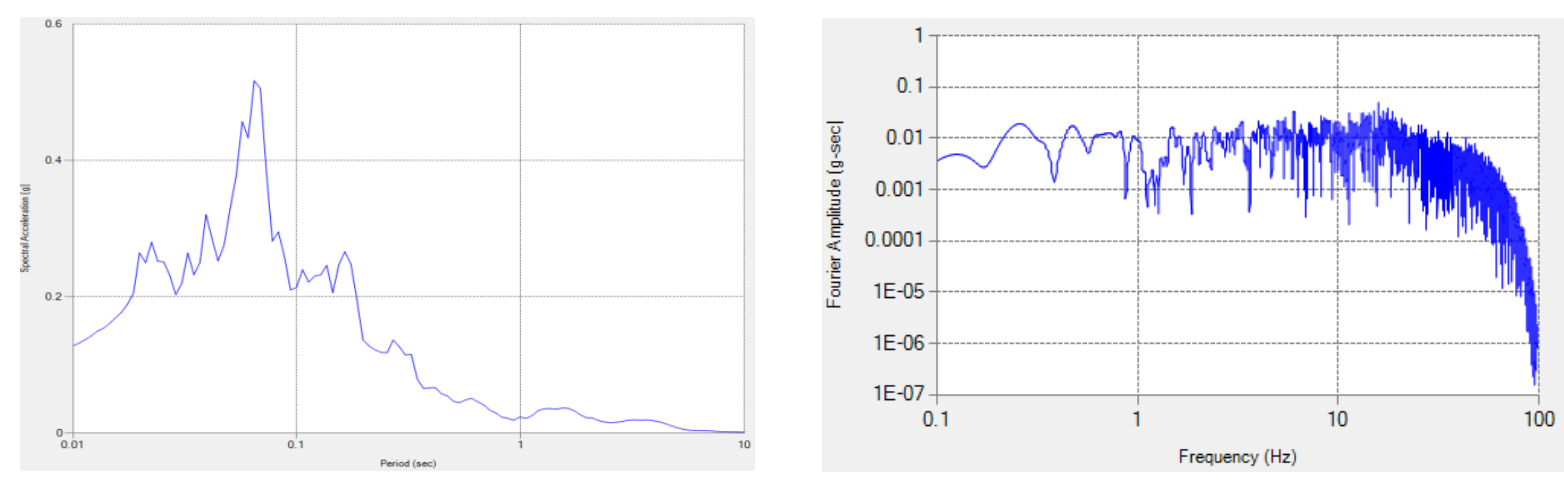

Figure 3. Result of spectral acceleration and Fourier amplitude analysis at the borehole K8.
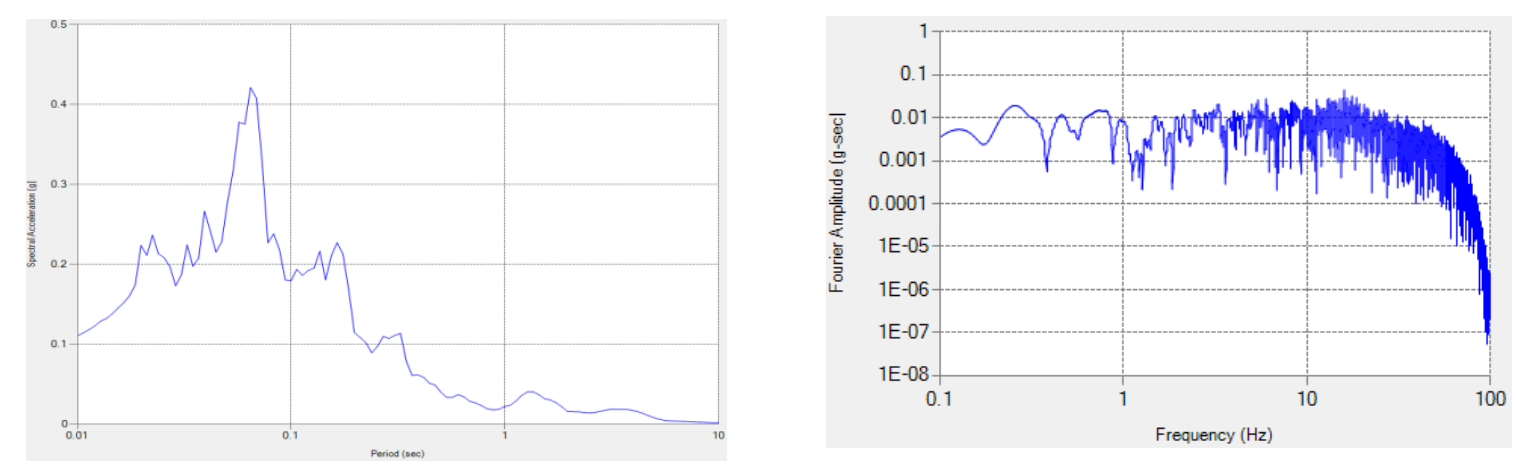

Figure 4. Result of spectral acceleration and Fourier amplitude analysis at the borehole 1, Chua Boc. 

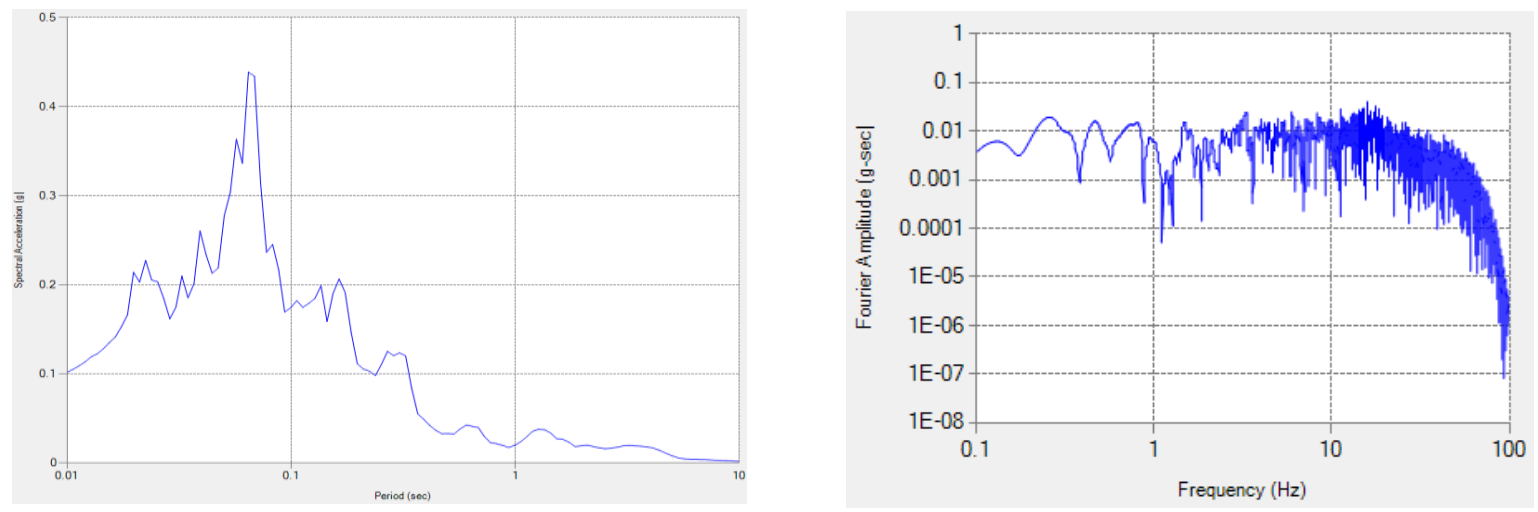

Figure 5. Result of spectral acceleration and Fourier amplitude analysis at the borehole 1, My Dinh 2.
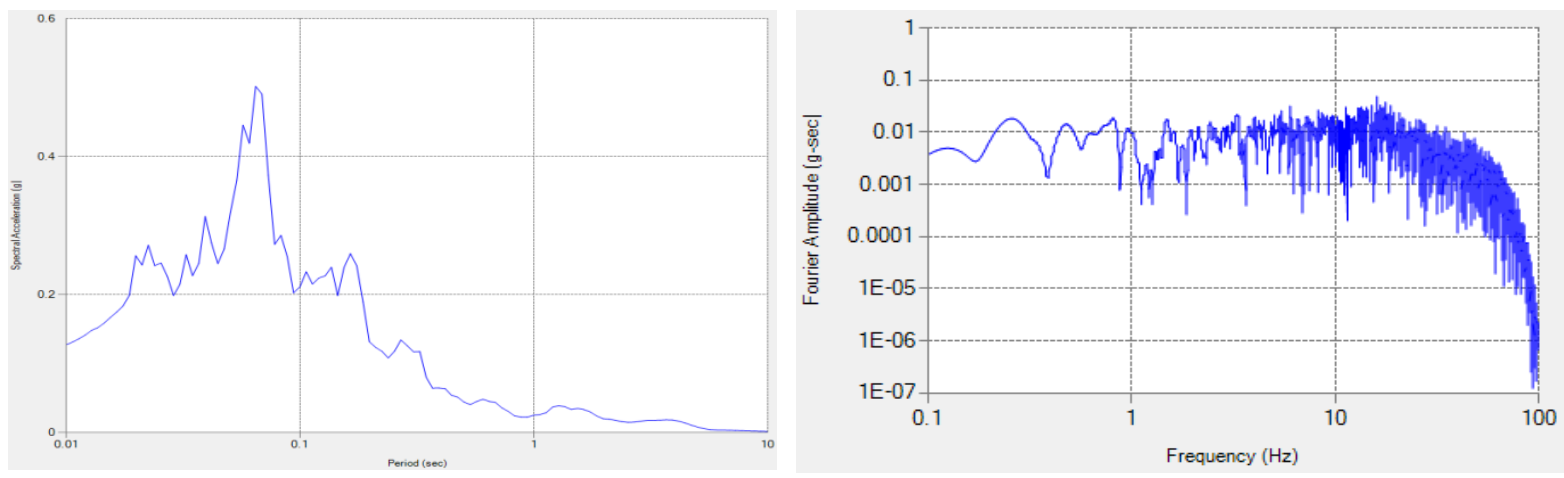

Figure 6. Result of spectral acceleration and Fourier amplitude analysis at the borehole K1.

Analyzing the soil profile of four boreholes, it can be seen that the response spectrum accelerations are slightly different. The values of response acceleration vary around $0.4 \mathrm{~g}$ to $0.6 \mathrm{~g}$ in four boreholes. The highest acceleration of $0.52 \mathrm{~g}$ is in the borehole CT2 North Linh Dam, Hanoi while the lowest value is $0.42 \mathrm{~g}$ belonging to the bore hole at Chua Boc, Hanoi. These results are completely suitable with the site classification for Hanoi city above.

\section{Conclusion}

It is the first time, the site response analysis with the real geological conditions of Hanoi area has been done to assess its effects in the case earthquake happen. The value of site response acceleration in Hanoi areas varies from $0.4 \mathrm{~g}$ to $0.6 \mathrm{~g}$.

Due to the input data limitation, the obtained results are not satisfied as our expectation on the seismic hazard evaluation. We do hope that in the future, with more soil profiles collected from deeper boreholes in different areas of Hanoi area in combination with further new method applications, the results to study on seismic site response analysis for some areas in Hanoi city will be more detailed and effectively. 


\section{Acknowledgments}

This research is funded by the VNU University of Science under project number TN.17.05

\section{References}

[1] Bard P. Y., Local effects on strong ground motion: Physical basis and estimation methods in view of microzoning studies, Lecture and exercise notes of International Training Course on Seismology, Seismic Hazard Assessment and Risk Mitigation, Beijing - China, 1999.

[2] Pham Dinh Nguyen, Evaluate the effect of local conditions on strong ground motion, Thesis for the degree Master of Science, Hanoi University of Sciences - VNU, 2002.

[3] A. Replumaz, R. Lacassin, P. Tapponnier, and P. H. Leloup, Large river offsets and PlioQuaternary dextral slip rate on the Red River fault (Yunnan, China), Journal of Geophysical Research, Vol. 106, No. B1, 2001, 819.

[4] Vy Quoc Hai, Tran Quoc Cuong, Nguyen Viet Thuan, Crustal movement along the Red River Fault zone from GNSS data, Vietnam Journal of Earth Sciences, 38 (1), 2016, 14.

[5] Ngo Van Liem, Phan Trong Trinh, Hoang Quang Vinh, Nguyen Van Huong, Slip rates during the Middle-Late Pleistocene period along Red River Fault Zone in Lao Cai - Viet Tri section, Vietnam Journal of Earth Sciences, 33 (3, Special Issue), 2011, 465.

[6] Tran Dinh To, Nguyen Trong Yem, Duong Chi Cong, Vy Quoc Hai, Witold Zuchiewicz, Nguyen Quoc Cuong, Nguyễn Viết Nghĩa, Recent crustal movements of northern Vietnam from GPS data, Journal of Geodynamics (69), 2013, 05.

[7] Witold Zuchiewicz, Nguyen Quoc Cuong, Jerzy Zasadni, Nguyen Trong Yem, Late Cenozoic tectonics of the Red River Fault Zone, Vietnam, in the light of geomorphic studies, Journal of Geodynamics 69, 2013, 11.

[8] K. L. Wen, C. M. Lin, C. H. Kuo, N. H. Phuong and N. T. Hung, Microzonation Study in the Hanoi, Vietnam, 10th International Workshop of Seismic
Microzoning and Risk Reduction, September 25, 2013.

[9] Rabin Tuladhar, Nhu Nguyen Hong Cuong, Fumio Yamazaki, Seismic microzonation of hanoi, vietnam using microtremor observations, 13th World Conference on Earthquake Engineering, Vancouver, B.C., Canada, 2004.

[10] N. H. Phuong, Geologic map of Hanoi. Marine Data Management Department, National Center for Natural Science and Technology of Viet Nam, Vietnam, 2001.

[11] International Code Council, International Building Code, Publications, 4051 West Flossmoor Road, Country Club Hills, IL 60478, USA, 2009.

[12] Phan Trong Trinh, Ngo Van Liem, Nguyen Van Huong, Hoang Quang Vinh, Bui Van Thom, Bui Thi Thao, Mai Thanh Tan, Nguyen Hoang, Late Quaternary tectonics and seismotectonics along the Red River fault zone, North Vietnam, EarthScience Reviews 114, 2012, 224.

[13] Bui Thi Nhung, Nguyen Hong Phuong, Local site classification for the urban region of Hanoi city, Vietnam Journal of Earth Sciences, 37(4), 2015, 363.

[14] Nisha P. Naik and Deepankar Choudhury, Comparative Study of Seismic Ground Responses Using DEEPSOIL, SHAKE and D-MOD for Soils of Goa, India, Geo-Congress Technical Papers, GSP 234 @ A ASCE, 2014.

[15] S. J. Lasley, R. A. Green and A. Rodriguez Marek, Comparison of Equivalent-Linear Site Response Analysis Software, 2014.

[16] Marto, A., Soon, T. C., Kasim, F., and Suhatril, M., A Correlation of Shear Wave Velocity and Standard Penetration Resistance. EJGE, Vol. 18, Bund. C., 2013, 463 .

[17] Himanshu Jhinkwan, P. K. Jain, Prediction of shear wave velocity using SPT - $\mathrm{N}$ value, International Journal Of Current Engineering And Scientific Research, Vol-3, 2016, 28.

[18] Hashash, Y. M. A., Musgrove, M. I., Harmon, J. A., Groholski, D. R., Phillips, C. A., and Park, D., DEEPSOIL 6.1, User Manual, 2016.

[19] Vu Thi Hoan, Ngo Thi Lu, Mikhail Rodkin, Nguyen Huu Tuyen, Phung Thi Thu Hang, Tran Viet Phuong, Prediction of maximum earthquake magnitude for northern Vietnam region based on the gev distribution, Vietnam Journal of Earth Sciences, 38(4), 2016, 339. 


\title{
Phân loại nền và phân tích phản ứng của nền đất cho một số khu vực ở thành phố Hà Nội khi có động đất xảy ra
}

\author{
Giang Kiên Trung ${ }^{1}$, Nguyễn Đức Vinh ${ }^{1}$, Đặng Thị Mến ${ }^{2}$ \\ ${ }^{1}$ Khoa Vật lý, Trường Đại học Khoa học Tự nhiên, ĐHQGHN, 334 Nguyễn Trãi, Hà Nội, Việt Nam \\ ${ }^{2}$ K58 Chuơng trình đào tạo chuẩn Quốc tế, Trường Đại học Khoa học Tự nhiên, ĐHQGHN, \\ 334 Nguyễn Trãi, Hà Nội, Việt Nam
}

Tóm tắt: Cùng với sự phát triển của thành thị và cuộc sống hiện đại, Thủ đô Hà Nội đang xây dựng thêm ngày càng nhiều các công trình lớn như nhà cao tầng, các cây cầu hiện đại hay những công trình ngầm. Theo những nghiên cứu đã được tiến hành, Hà Nội nằm trên một khu vực có nền đất yếu gồm những lớp trầm tích dày, có cấu trúc địa chất phức tạp và tầng nước ngần nông thuộc lớp Holocene và Pleistocene. Bên cạnh đó thành phố Hà Nội bị cắt ngang bởi đứt gãy sông Hồng. Đây được xem là một đới đứt gãy vẫn đang hoạt động mạnh và nó có thể gây ra động đất có độ lớn $\mathrm{M}=6,1$ tương ứng với vùng chấn động cực đại cấp 7 . Với mục đích dự đoán để lên kế hoạch dự phòng nhằm hỗ trợ cũng như làm giảm những tổn thất về người và tài sản khi có động đất xảy ra tại Hà Nội. Chúng tôi tiến hành tìm hiểu, nghiên cứu về địa chất thực tế của khu vực Hà Nội kết hợp với việc phân tích số liệu một số lỗ khoan của khu vực nội thành Hà Nội. Từ đó chúng tôi tìm được những yếu tố địa chất, vật lý đặc trưng của khu vực. Các thông số này được dùng làm đầu vào cho chương trình DeepSoil để sử dụng cho việc mô phỏng, đánh giá hiệu ứng nền của Hà Nội khi xảy ra động đất.

Tư khóa: Mô phỏng, điều kiện nền địa phương, phân tích hiệu ứng nền địa chấn, dao động nền, phân loại nền. 